\section{De kinesiske tegns udvikling og opbygning}

af forskningsbibliotekar Bent Lerbak.

Pedersen, Det Kongelige Bibliotek

$\mathrm{I}$ oktober 1932 blev et kinesisk avissætteri beskrevet i det danske blad »Pilestræde«. Forfatteren undrede sig over, at kineserne ikke havde valgt at gå over til et alfabet, da sætningen af en avis- eller bogside var meget besværlig og krævede mange sættere. Desuden fremhævede forfatteren den lethed, med hvilken et nyt ord, navn eller sjældent brugt ord kunne gengives ved hjælp af alfabetet, mens man i Kina måtte skære et helt nyt tegn til sætterne. Denne artikel illustrerer europæernes uvidenhed om den kinesiske kultur, og hvad der ligger bag ved de kinesiske tegn og deres betydning.

I Kina har mange veluddannede mennesker i tidens løb spekuleret over tegnenes oprindelse. Nogle af forklaringerne bygger på mytologien, som f.eks. at en gud i tidernes morgen var blevet inspireret af fuglenes fodaftryk i sandet til at opfinde skriften. Andre forklaringer var mere akademiske. De første teorier blev fremført af forfatterne til den første ordbog, man kender i Kina. Den blev udgivet i 121 e.v.t. af Xu Shen (ca. 58-147 e.v.t.) under navnet »Shuowen jiezi« (Forklaringer på tegnene og deres udgangspunkt). Den indeholder ca. 9.000 tegn med tilhørende forklaringer på de enkelte tegns udgangspunkt, og forfatterne fremfører tre mulige forklaringer på selve oprindelsen af tegnene.

Under den legendariske kejser Huangdi skulle en mand ved navn Cang Jie have haft ansvaret for rigets historie, og han skulle derfor have opfundet skriften for at kunne gemme diverse oplysninger uden nødvendigvis at skulle have det hele i hovedet. Han lod sig inspirere af himlen og naturen og dens skabninger til udformningen af tegnene. En anden teori bygger på et sæt af symbolske tegn, der skulle gengive de vigtigste naturelementer i verden. Dette system har otte basistegn, der består af tre stregelementer i forskellige kombinationer. De kaldes på kinesisk for »bagua«, der traditionelt oversættes med »de otte trigrammer« (fig. 1).

Dette er forklaring nummer to på, hvordan skrifttegnene skulle være udviklet. Endelig anfører Xu Shen endnu en mulighed, der går ud på, at skriften er en videreudvikling af et enkelt knudesystem, hvor optegnelse af informationer skete ved at slå knuder på snore. Et sådant rebknudesystem kendes i det 20. århundrede fra Centralasien og fra en minoritetsgruppe i det sydvestlige Kina, men her benyttes systemet kun til en form for opregning af ting eller emner, ikke som et egentligt skriftsystem.

Disse tre forklaringer og selve ordbogens optegnelser af tegnenes udgangspunkt har dannet baggrund for kinesernes forsøg på at finde tegnenes oprindelse. Man havde ikke videre kendskab til de meget tidlige tegn for 


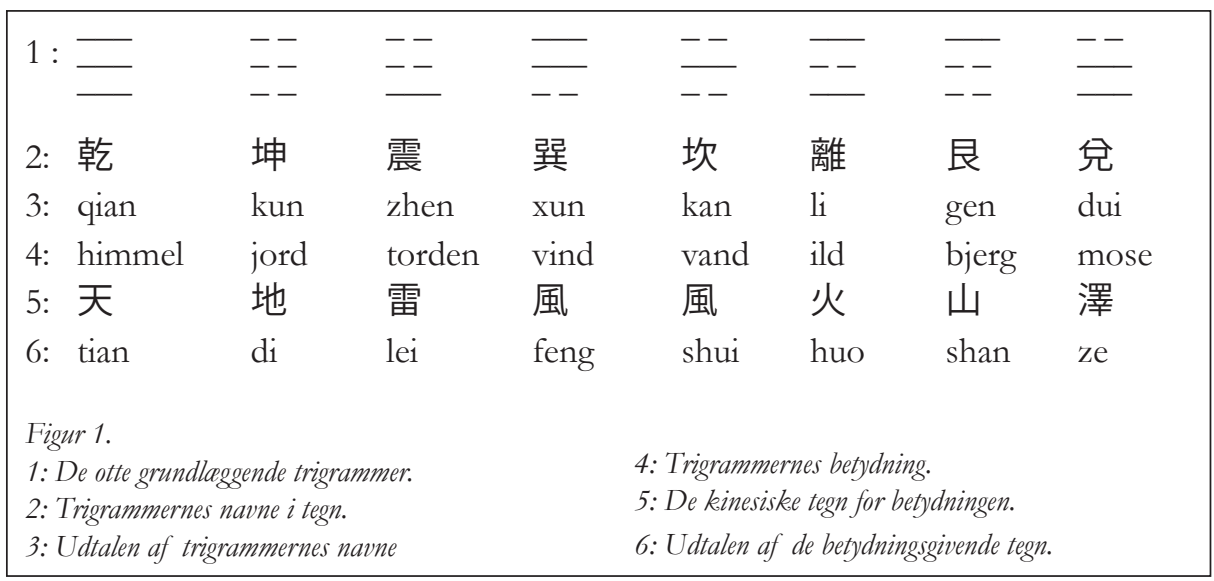

slutningen af det 19. århundrede. I begyndelsen af det 20. århundrede dukkede nye oplysninger op takket være en pudsig hændelse. I Beijing i sommeren 1899 blev den oldkyndige filolog Wang Yirong (1845-1900) syg, og hans ven og kollega Liu E (18571909) gik til det nærliggende apotek for at købe medicin til ham. På apoteket lagde han mærke til nogle mærkelige indridsninger på nogle benstykker og skildpaddeskjold kaldet »drageben«, der blev pulveriseret og anvendt i forskellige former for medicin, og det slog Liu $\mathrm{E}$, at indridsningerne faktisk lignede skrifttegn. Da Wang blev rask igen, gik de to venner rundt på alle apoteker $\mathrm{i}$ Beijing for at opkøbe disse benstykker og skjolde. Dette var begyndelsen på udforskningen af de tidligste kinesiske tegn, der kendes i dag. Benstykkerne og skjoldene kom fra en bestemt lokalitet i Henanprovinsen lige uden for byen Anyang. På udgravningsstederne for ben- og skjoldstykkerne fandtes efterladenskaber af huse, grave og helligsteder, og arkæologerne fik nu historiske be- viser for eksistensen af Shangdynastiet (ca.1400-1100 f.v.t.), der hidtil havde været betragtet som legendarisk.

Disse tegn kaldes for orakelbenskrift, da benene og skjoldene oprindelig blev brugt til spådomstagninger for herskerne i Shang ved religiøse ceremonier. Tegnene gengav spørgsmål til guderne, og i nogle tilfælde ses også svarene og de efterfølgende hændelser indridsede. Den kinesiske betegnelse for dem er Jiagu wen, hvilket på dansk betyder skjold (jia), ben (gu) og skrift (wen). Tegnene blev systematisk skrevet i lodrette kolonner fra højre mod venstre - ganske som man senere, og til dels stadigvæk, skriver tegn i kinesiske dokumenter og bøger. Selvom disse tegn er tidlige, er de meget udviklede og ganske komplicerede. Det betyder, at der må have været endnu tidligere udgaver af de kinesiske tegn, men der er stadigvæk ikke fundet endegyldige beviser for eller forklaringer på tegnenes oprindelse, så forskerne må indtil videre nøjes med at gætte sig frem på grundlag af materiale fra de arkæologiske udgravninger. 


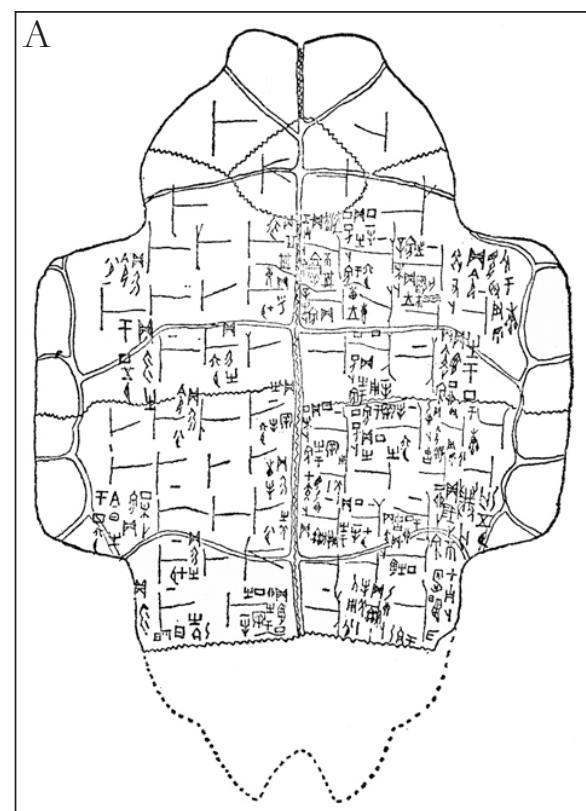

Figur 2. Orakelbensskrift. A. Tegning af skildpaddeskjold fra Anyang, ca. det 11. årbundrede f.v.t.

Kinesiske arkæologer har fundet visse indridsede symboler på potteskår fra de to yngre stenalderkulturer Yangshao (5000-3000 f.v.t.) og Majiayao (3300-2500 f.v.t.) fra hhv. det centrale og nordvestlige Kina. Enkelte potteskår fra disse kulturer har indridsede symboler, der måske kan ses som forsøg på en form for optegnelse af information, men de ses enkeltvis uden sammenhæng, så de er måske blot symboler på ejerskab, pottemagerens varemærke eller navn. En del af tegnene er måske de første taltegn man kender, f.eks. modsvarer - , 三, X sandsynligvis de moderne tal 1, 3 og 5 (一, 三, 五).

Nogle lerkar fra yngre stenalder (4300-2000 f.v.t.), der er fundet i det østlige Kina i Shandongprovinsen, har tydeligere indridsninger, der stærkt min-
B

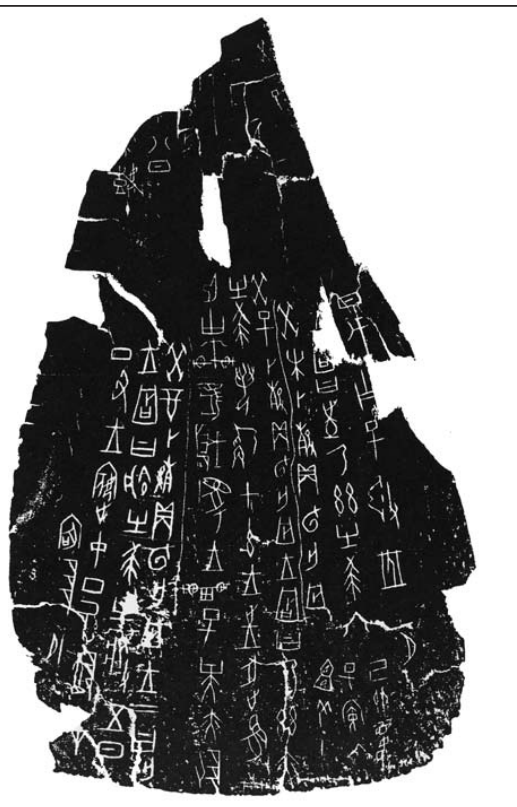

B. Afgnidning af skulderblad fra en okse udgravet ved Anyang, det 13. arrbundrede f.v.t.

der om nogle senere tegn. F.eks. er der fundet et symbol, der ligner tegnet for morgengry, $\frac{1}{y}$, der i dag har formen 트 (dan), mens et andet symbol ligner det moderne tegn for økse, $\approx$, 斤(jin).

Da man hidtil kun har fundet et begrænset antal symboler, som kan relateres til senere tegn, er det ikke muligt at afgøre, hvorvidt man står over for de oprindelige tegn eller ej. De er interessante kandidater til Kinas tidligste skrifthistorie, men indtil videre er de første rigtige læsbare og forståelige tegn dem, vi finder i tekster fra Shangtiden.

\section{De kinesiske tegns opbygning}

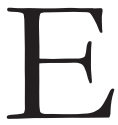
n del europæere tror, at kinesiske tegn er en billedtegnskrift, men dette er kun delvist sandt, da et sprog ikke kun kan klare sig med 

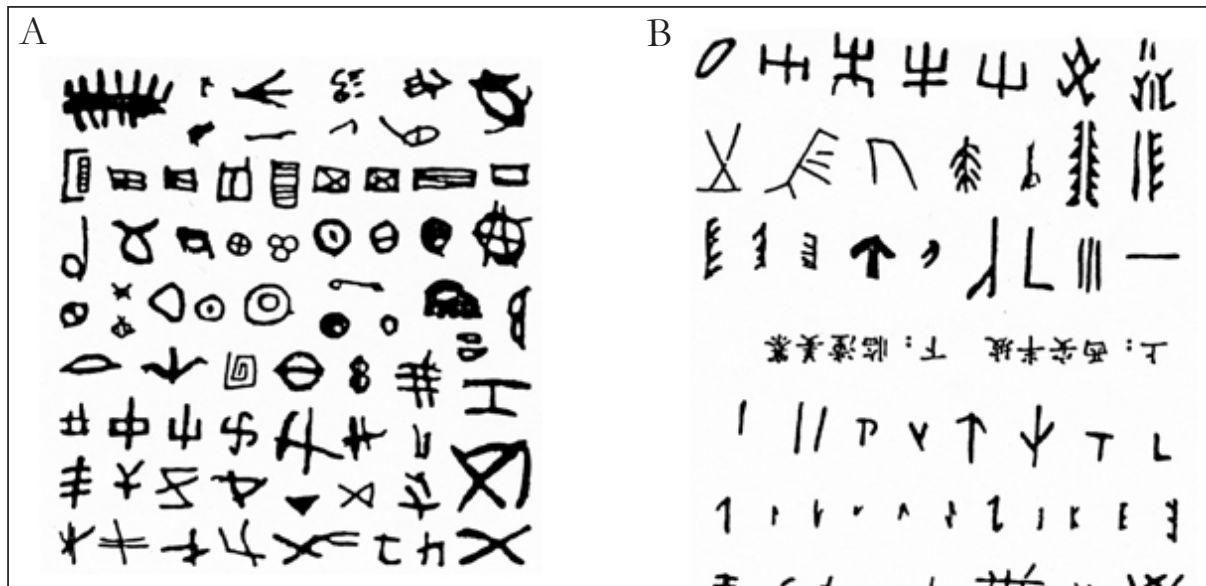

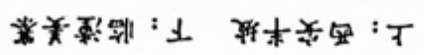

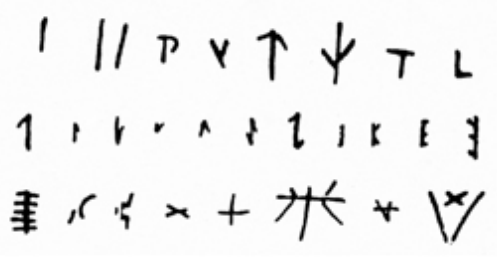

Figur 3.

A. Fra Yangshaokulturen.

Yangshaoog Majiayao-symboler på potteskår.

B. Fra Majiayaokulturen.--

genstande og hændelser, der kan gengives i billeder. Mange abstrakte begreber er for vanskelige og komplicerede til at kunne udtrykkes med et billede, der kan opfattes entydigt. I dag er det under $10 \%$ af tegnene, der kan kaldes egentlige billedtegn. Kinesiske forskere er dog af den mening, at billedtegn må høre til den ældste skriftform. Af disse udvikledes tegnene med idékombinationer og blev til såkaldte afledte tegn. Billedtegn er enkle billeder af genstande og hændelser fra naturen og menneskers virke. Ved at udvide de enkelte billeder med små stregtilføjelser kan man tegne nye, relaterede. F.eks. anbringes en streg på toppen af tegnet for træ 木 til 末, hvorved man făr betegnelsen for en gren, mens en streg forneden på tegnet for træ, 本, giver betydningen rod. Disse tilføjelser kaldes for markører og kan blive ganske sofistikerede, som f.eks. betegnelsen for noget sødt: Tegnet for mund, $\boldsymbol{U}$ (formen i dag $\square$ ), får en streg i centrum, $\boldsymbol{\Theta}$, for at angive en tunge, der smækker lystigt i mundhulen, mens en streg over en mund, $\boldsymbol{U}$, angiver begrebet »at tale« - dvs. en tunge, der vipper uden for munden.

Nogle billedtegn kunne desuden få en abstrakt betydning, afledt af tegnets oprindelige betydning. F.eks. angives »en dag« med et billede af solen, 日 (ri), der netop giver dagslys. Billedet af en høj bygning, 高 (gao), kan også angive, at noget er højt. Abstrakte begreber udtryktes med enkle billeder: »Over« blev angivet med en lille streg over en lidt længere streg, - , og »under« med en lille streg under den lidt længere, $=$. I dag ses begge tegn med en lille markør, formodentlig for at tydeliggøre tegnene: 上 (shang) for »over« og 下 (xia) for »under«.

Nogle billedtegn kunne sættes sammen og give en ny betydning med 
relation til den oprindelige, f.eks. betyder et tegn bestående af to træer en skov, 林 (lin), mens tre træer sammen, 森 (sen), giver associationer til noget dunkelt og derfor kom til at betyde noget mørk eller - mere abstrakt - dyster alvor. To eller flere tegn blev også sat sammen for at give en beslægtet eller afledt betydning af tegnene, som f.eks. ved at sætte sol, 日, og måne, 月, sammen, 明, til at betegne noget klart og lysende. Tegnet for hus, $\dot{\sim}, \mathrm{i}$ forkortet form sat sammen

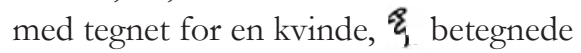
noget eftertragtelsesværdigt og kom til at betyde »fred «, 国 (moderne form 安), mens kombinationen af tegnene for kvinde og barn viste noget idyllisk og kom til at stå for ngod《, 蜉 (moderne form 好). En del handlinger kan også vises efter denne metode, men med de to tegn sat sammen til ét, som f. eks. i wat plukke«, der består af tegnene for en hånd og et træ med frugt, form 采), eller »at skyde«, hvor tegnet for en pil er lagt over tegnet for en bue, $4<$ (moderne tegnform for bue 弓).

Det er klart, at der skal være enighed om, hvad billedtegnene og især deres sammensætninger og afledninger betyder, for ellers vil læseren få problemer med tekster skrevet af andre mennesker $o g$ fra andre steder end vedkommendes eget nære samfund. Dette var til en vis grad problemet med nogle af de tidlige tekster, der blev nedskrevet i de forskellige stater $i$ tiden for det første kejserrige (Qindynastiet 221-207 f.v.t.).

I Qindynastiet gennemførtes med held en standardisering af tegnene, således at tegnvarianterne for det samme begreb eller den samme genstand blev minimeret. Hovedparten af tegnene i de tidlige tekster var dog let genkendelige for de højtuddannede, men standardiseringen lettede alligevel læsningen og derved forståelsen af teksterne.

Billedtegn og deres sammensætninger og afledninger kunne dog ikke alene dække hele ordforrådet i sproget. Derfor måtte man finde en metode, som kunne danne tegn til at afhjælpe denne mangel. En del ord udtaltes ens, så det var muligt at låne tegn fra ord, der havde samme udtale med ord, som endnu ikke havde et tegn. Dvs. at man overførte tegnet fra $\mathrm{f}$. eks. »hvede« med udtalen »lai« til ordet (»lai«), der betød "at komme«, eller tegnet for bjørn (udtales xiong) blev også anvendt for verbet »at være i stand til« med samme udtale (xiong). En del af disse lån kom til at overtage det oprindelige tegn, da dette gled ud af brug, men $i$ andre tilfælde stod man nu med ét tegn med to forskellige betydninger, hvilket selvfølgelig gav mulighed for forvirring og misforståelser. Løsningen var at tilføje en lille ekstra streg til det oprindelige tegn i en af formerne, således at der nu kunne skelnes mellem betydningerne. F.eks. er tegnet for »en kurv«, 其, ganske vellignende, men i den lånte udgave betyder det tredje person i ejefald. Da en kurv ofte blev fremstillet af bambus, tilføjede man derfor tegnet for bambus, 竹, $i$ formindsket udgave til tegnet for »en kurv«, 箕, og det oprindelige tegn blev derefter udelukkende brugt i betydningen "hans«, »hendes«, »deres«.

Men også denne metode havde sine begrænsninger, og der manglede 


\begin{tabular}{|c|c|c|c|c|c|}
\hline & & Tidlig & Nuvæ & & \\
\hline & & form & form & Lyd & Beskrivelse \\
\hline Menneske: & Menneske & $\lambda$ & 人 & ren & gående person i profil \\
\hline & Kvinde & 只 & 女 & nü & knælende person \\
\hline & $\varnothing \mathrm{je}$ & $\cos$ & 目 & $\mathrm{mu}$ & omrids af øje med pupil \\
\hline Natur: & Sol & $\odot$ & 日 & ri & solens omrids prik \\
\hline & Regn & 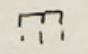 & 雨 & yu & sky med faldende dråber \\
\hline & Vand & E & 水 & shui & vandløb og bredder \\
\hline & Træ & 次 & 木 & $\mathrm{mu}$ & stamme med fire grene \\
\hline Dyr: & Hest & & 馬 & ma & hest i profil \\
\hline & Fugl & 3is) & 鳥 & niao & fugl i profil \\
\hline & Fisk & 鼠 & 魚 & yu & fisk i profil \\
\hline Genstande: & Kniv & $\int$ & 刀 & dao & æggen på en kniv \\
\hline & Vogn & $-7 x^{2}$ & 車 & che & hjul og ramme set fra oven \\
\hline & Pil & l. & 失 & shi & pil i profil \\
\hline & Kogekar & 橧 & 鼎 & ding & kar over ild \\
\hline
\end{tabular}

Figur 4. Kinesiske billedtegn.

stadigvæk tegn for mange ord. Når man sammenstillede forskellige tegn eller lånte tegn, endte man undertiden med, at et af tegnelementerne stod for udtalen og et anden for betydningen. Dette blev sat i system, hvorved et tegn, der angav betydningen, fik inkorporeret et tegn, der angav lyden - udtalen. Tegnet for »kød«, 肉 (med udtalen »rou«), fik tilføjet tegnet »fang«, 方, der betyder »kvadratisk«. Den nye kombination af de to tegn, 肪, fik betydningen »dyrefedt« med udtalen »fang«. På den måde mistede den højre del af det nye tegn sin betydning, men beholdt udtalen. Den venstre del af tegnet mistede sin udtale, men beholdt en betydning, der kom tæt på den oprindelige som $\mathrm{i}$ dette tilfælde, hvor meningen skiftede fra »kød« til »dyrefedt«. Ligeledes kom tegnet for »et øre«, 耳 (med udtalen »er(), i kombination med udtalen af tegnet, 令, »ling« (med betydningen »at kommandere«), til at betyde »at høre«, 聆, med udtalen »ling«. Denne metode har vist sig at være en effektiv løsning på 
tegnudviklingen i det kinesiske sprog.

I Vesten kaldes betydningsdelen for radikalen og lyddelen for fonetikum. Denne opdeling ses allerede i den føromtalte ordbog, Shuowen jiezi, der arbejder med 540 radikaler, men de er senere blevet reduceret til 214, og det er det antal, der i dag anvendes i de fleste moderne kinesiske ordbøger.

Kineserne anvender stadig kombinationen af betydning og lyd, når nye tegn skal dannes. De kemiske og metallurgiske betegnelser lånt fra Vesten kombineres med en lyddel og en betydningsbærende del, der afspejler den grundlæggende idé bag ordet. F.eks. skrives den kemiske betegnelse Se (for selenium) med betydningen »sten«, 石 (shi), og lyden, »xi«(西), i sammensætningen 硒. Den oprindelige betydning af »xi«, 西, er »vest«, og har således intet tilfælles med tegnet for »selen«. Metal, 金 (jin), og lyden »ge« (各) danner betegnelsen for »krom« (Cr), 鉻. Tegnet »ge«, 各, betyder »enhver af dem« eller »forskellig«.

Når man skal skrive fremmede navne med kinesiske tegn, anvender man tegn, der har lydlighed med stavelserne i navnene. Man vælger selvfølgelig tegn, der ikke kan vække anstød, og helst finder man nogle med poetiske referencer. Således udtales »Danmark « som »danmai« og med tegnet, 丹麥, der direkte oversat betyder »rød hvede«. Man kan sagtens se et Dannebrog blafre mellem kornmarker for sig.

\section{Udviklingen af tegnenes former}

om ovenfor nævnt standardiseredes tegnene i det første kejser$\bigcirc$ rige Qin. Qin samlede en række uafhængige kongeriger til én stat, hvilket ikke havde været tilfældet i mange hundrede år. Hvert af de enkelte kongeriger havde deres egne foretrukne varianter af skrifttegnene, så embedsmændene i Qinstaten besluttede med kejserens velsignelse at vælge én skriftform som standard. Denne form kendes under navnet 小管, xiaozhuan (den lille seglskrift), da den oftest havde været anvendt som inskription på segl. Den var relativ enkel, men krævede dog alligevel stor skriftkyndighed, da alle streger i tegnene skulle tegnes med lige tykke streger, og tegnene skulle have samme størrelse, ligegyldigt hvor mange streger der var i de enkelte tegn. Den lille seglskrift viste sig ikke særlig egnet til dagligdagen, så en modificeret stil opstod. Denne stil kendes under navnet lishu, 隸書 (den officielle stil), og var meget skrivevenlig. Stilen var elegant og tillod, at de enkelte dele i et tegn blev skrevet med varierende tykkelse. Denne egenskab var især velegnet til pensel og tusch, der blev de foretrukne skriveredskaber i det gamle Kina. Selv i dag anvender man pensel og tusch, når man vil skrive smukt og stilfuldt.

Lishustilen var dog stadig lidt for stiv, så hen mod slutningen af $\operatorname{det} 2$. århundrede e.v.t. opstod en ny stil, der var mere læsevenlig. Stilen kaldes 楷 書, kaishu (den regulære stil), og blev standardskriften i Kina helt op til i dag. Hovedparten af alle tekster er blevet og bliver stadig trykt i denne stil. Den er tydelig, meget læsevenlig og de enkelte strøg i tegndelene er anbragt efter klare regler. Selvom stilen i princippet kun findes i én form, har der i tidens løb 
været en del variationer i udformningen, således at der også var plads til mere kunstneriske former. Netop variationer $i$ tegnudformningen er en vigtig kvalitet for den kinesiske lærde. Han (og i dag også hun) lægger stor vægt på at kunne skrive tegn i variationer, der udtrykker den skrivendes personlighed. Det er gennem kalligrafien og maleriet, at de kinesiske lærde har kunnet udtrykke deres sindstilstande og personlige idérigdom, som det ikke var påskønnet at give udtryk for gennem direkte handlinger og følelsesbetonede tekster. Kinesiske tekster, det være sig digte, romaner, rapporter, historieskrivning eller faktatekster, der er skrevet i en kalligrafisk form, viser desuden en enestående samhørighed mellem tegnenes betydning, udseende og lyd, som ikke er mulig i mange andre kulturers skriftsystemer.

Med kaishustilen som baggrund udvikledes yderligere to stilarter, der gav mulighed for endnu flere variationer. Den ene af dem er en slags hurtig form for kaishu og kaldes da også for 行書, xingshu (den løbende stil). Denne stil benytter strøg, der ofte făr de enkelte tegndele til at løbe sammen med en meget smuk og kraftfuld virkning. Det er stadig muligt at læse tekster skrevet i den løbende stil, omend med noget besvær, hvilket man ikke kan sige om den anden af de kalligrafiske former. Den er en slags abstraktion, hvor de

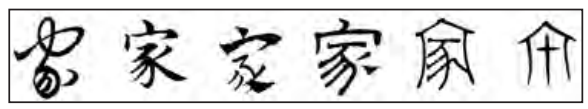

Tegnet for familie, "jia", i lille segl-, lishu-, kaishu-, xingshu- og caoshu-stilene. enkelte dele i tegnene ofte smelter sammen i uigennemskuelige dele. Stilen kaldes for 草書, caoshu (græsskrift), og kan virke meget ekspressionistisk. Mange berømte kalligrafer anvender denne stil, men for at læse teksten skal man helst kende den først, ellers er den næsten ikke til at tyde.

Da det kommunistiske styre kom til i oktober 1949, mente ledende partimedlemmer, at der var behov for en skriftrevision. De fandt, at de kinesiske tegn var for besværlige at huske og skrive for de store masser, og de ønskede, at hele den kinesiske befolkning skulle kunne læse og skrive. Hidtil var det kun en forholdsvis lille elite, der kunne skrive og læse perfekt, mens en lille gruppe af den øvrige del af befolkningen kun kunne læse og skrive nødtørftigt. For at bekæmpe analfabetisme mente en del kommunistiske sprogforskere, at det var nødvendigt med en omformning af de kinesiske tegn. Der var desuden en del af dem, der gerne ville arbejde hen mod en afskaffelse af de kinesiske tegn og basere skriften på det latinske alfabet.

Idéerne om en revision af tegn og indførelsen af et alfabet var allerede opstået i slutningen af det 19. århundrede bl.a. på grund af påvirkninger fra den vestlige kultur. Indførelsen af et alfabet i det kinesiske sprog er imidlertid forbundet med store vanskeligheder, da den kinesiske udtale i tidens løb er blevet stærkt forenklet. Mange tegn udtales ens, men har forskellig betydning, så for at adskille tegn med samme udtale, er der blevet tilføjet toner til tegnene. På den måde er det lettere at forstå hinanden $\mathrm{i}$ 


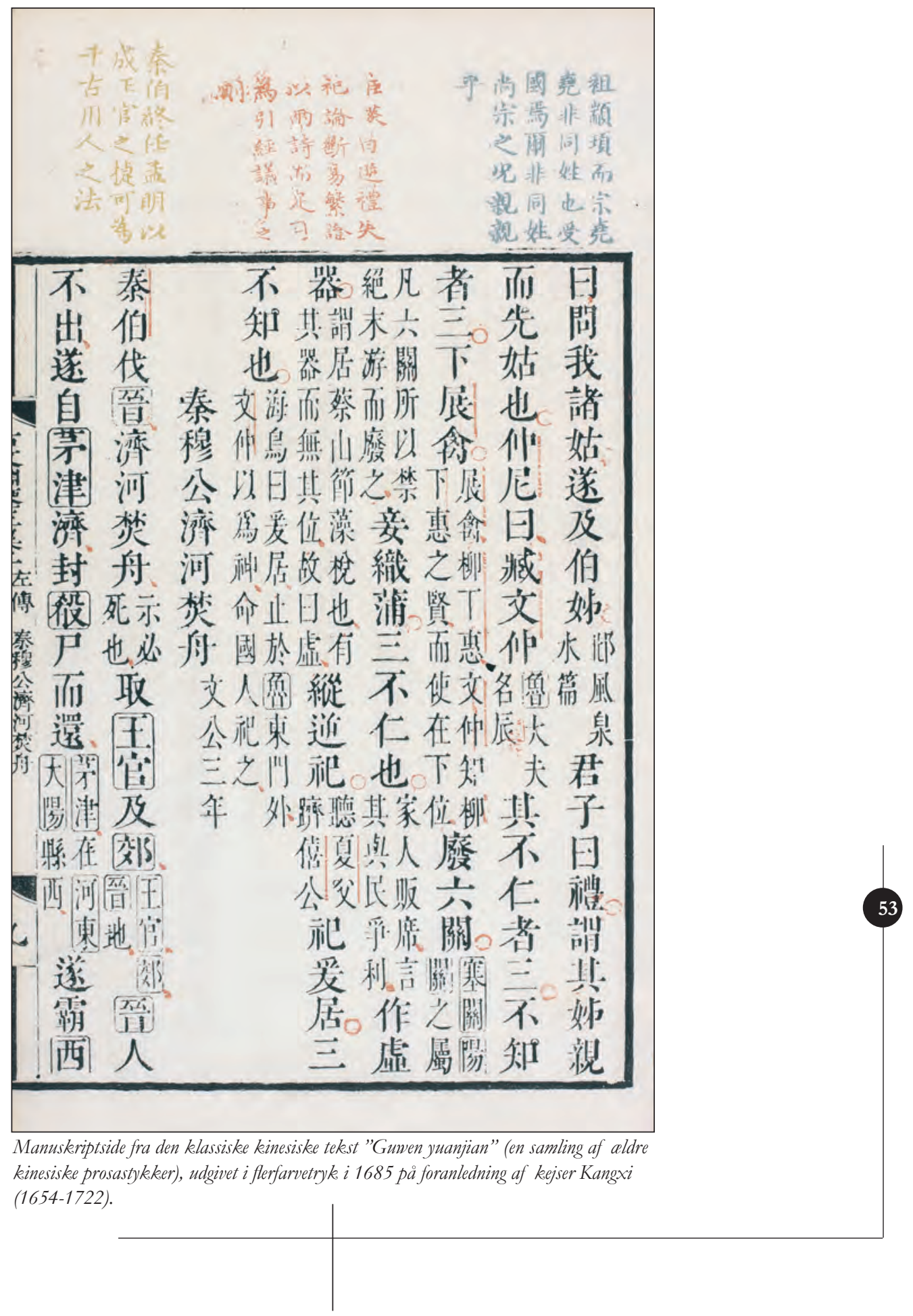


tale, selvom der stadig er mange tegn, der udtales ens og med samme tone. I standardkinesisk, kaldet mandarin eller pekingdialekt, findes fire toner og en neutral tone, der kun anvendes i meget få tilfælde. Visse sydlige dialekter har op til otte toner. Derfor er det vanskeligt at erstatte tegn med et alfabet. Dette har dog ikke hindret en lille gruppe kinesiske sprogforskere $i$ at forsøge at opfinde et system, hvorved det kunne lade sig gøre. Bl.a. blev der udviklet nogle fonetiske skriftsystemer, der stort set er opgivet $\mathrm{i}$ dag, men et af dem er bevaret på Taiwan, hvor det anvendes i de første skoleklasser og i en del ordbøger til beskrivelse af de enkelte tegns udtale. Det kaldes populært 國語注音, guoyu zhuyin (nationalsprog i fonetisk gengivelse), og blev udformet i 1913.

På denne baggrund besluttede regeringen i begyndelsen af 1950'erne at henlægge idéen om et alfabet til senere tider og påbegyndte en revision af tegnene. Man valgte at forenkle dem for på den måde at lette indlæringen og skrivningen af dem. Fra midten af 1950'erne kom de første forenklede tegn, og senere er flere blevet tilføjet. Det var nødvendigt at vælge faste principper for denne forenkling, og der er grundlæggende tre metoder, alt afhængig af hvilke typer af udformninger, man står over for:
1) Valg mellem forskellige tegnvarianter efter ideen om "folkelige" udgaver og færreste stregdele. F.eks. 村, cun (landsby), for $屯 \beta$, 矩, ju (en tommestok), for 智, 輝, hui (strålende, skinne), i stedet for 晻, 烧。

Af disse tre tegn har man valgt den første anførte form, da man mente, at den var hyppigst anvendt.

2) Anvendelse af gamle varianter med færre streger i tegnene. F.eks. fra den lille seglskrift valgtes 云, ”yun” (sky), frem for 雲 og 号, ”hao" (navn, nummer), for 號.

Fra det 11.-12. århundrede tog man f.eks. 旧, ”jiu” (gammel), i stedet for 舊.

3) Forenkling af tegn ved kun at bruge enkelte elementer af dem. F.eks. 寧, "ning" (med anden tone $=$ fredelig, i fjerde tone $=$ hellere), til denne enkle form 宁.

Ud over disse tre grundlæggende udvælgelsesmetoder forenklede man desuden en del radikaler, så de oftest optræder ens i forskellige tegn. F.eks. 言, "yan" (tale, ord), forkortes til $i$ og kan ses $i$ et tegn som 謝, "xie" (at takke), i denne form 谢 eller 車, "che" (vogn), til denne form 车, som bl.a. ses i tegnet "hui" 籬 (strålende, skinne).

Denne artikel er skrevet til Verdens skrifter. Redigeret af Stig T. Rasmussen. Forlaget Vandkunsten i samarbejde med Det Kongelige Bibliotek og Forening for Boghandværk. 2011. 392 s. Ill. ISBN 97887-2695-111-5. Kr. 299,95

Magasin fra Det Kongelige Bibliotek bringer løbende artikler derfra, skrevet af bibliotekets medarbejdere. 